\title{
Analysis of Agronomic Traits and Quarantine Diseases of Sugarcane Germplasms Newly Introduced from USA and Vietnem
}

Wei Jinju ${ }^{1}$ Song Xiupeng ${ }^{1}$ Zhang Ronghua ${ }^{1}$ Zhang Xiaoqiu ${ }^{1}$ Qin Zhenqiang ${ }^{1}$ Wei Chunyan ${ }^{1}$ Gui Yiyun ${ }^{1}$ Zhou Hui ${ }^{1}$ Tan Hongwei ${ }^{1} \quad$ Huang Dongliang $^{1}$ Li Haibi $^{1} \quad$ Wu Yang $^{2} \quad$ Li Yangrui $^{1} \bigvee \quad$ Liu Xihui ${ }^{1} \bigvee$

1 Guangxi Key Laboratory of Sugarcane Genetic Improvement, Guangxi Key Laboratory of Sugarcane Biotechnology and Genetic Improvement, Ministry of Agriculture, Sugarcane Research Center, Chinese Academy of Agricultural Sciences, Sugarcane Research Institute, Guangxi Academy of Agricultural Sciences, Nanning, 530007

2 Department of Biotechnology, Fujian Vocational College of Agriculture, Fuzhou, 350007

\Corresponding author Email: liyr@gxaas.net; xihuiliu2006@126.com

Molecular Plant Breeding, 2019, Vol.10, No.13 doi: $\underline{10.5376 / \mathrm{mpb} .2019 .10 .0013}$

Received: 11 Aug., 2019

Accepted: 08 Sep., 2019

Published: 16 Sep., 2019

Copyright (C) 2019 Wei et al., This article was first published in Molecular Plant Breeding (2019, 17(14): 4708-4716) in Chinese, and here was authorized to translate and publish the paper in English under the terms of Creative Commons Attribution License, which permits unrestricted use, distribution, and reproduction in any medium, provided the original work is properly cited.

Preferred citation for this article:

Wei J.J., Song X.P., Zhang R.H., Zhang X.Q., Qin Z.P., Wei C.Y., Gui Y.Y., Zhou H., Tan H.W., Huang D.L., Li H.B., Wu Y., Li Y.R., and Liu X.H., 2019, Analysis of agronomic traits and quarantine disease of sugarcane germplasm newly introduced from USA and Vietnem, Molecular Plant Breeding, 10(13): 100-107 (doi: $10.5376 / \mathrm{mpb} .2019 .10 .0013$ )

\begin{abstract}
The purpose of this study was to detect the status of Fiji disease virus (FDV) and leaf scald (Xanthomonas albilineans) in the newly introduced sugarcane germplasms from USA and Vietnam, and observe their agronomic performances in Guangxi sugarcane growing area, thus to provide references for screening healthy sugarcane germplasm. Following the quarantine procedure, 41 newly introduced sugarcane germplasm accessions were planted in isolated quarantine area for FDV and leaf scald detection. The PCR (RT-PCR) results showed the reaction to FDV and leaf scald were both negative and no quarantine disease occurred. Further, field experiments were conducted to observe their agronomic performance and resistance to commom diseases, like red rot, yellow spot, ring spot, pokkah boeng, mosaic, smut, rust and brown stripe diseases, and the results showed that 18 germplasm accessions were resistant to these diseases. Based on the experimental results, 8 accessions from USA and 4 accessions from Vietnam were selected for the next variety test. This study would provide excellent resistant germplasm materials and scientific references for further sugarcane disease resistance breeding.
\end{abstract}

Keywords Sugarcane germplasm, Disease, Quarantine, Molecular detection, Agronomic trait

Sugarcane (Saccharum officinarum) is the main sugar crop and cash crop in tropical and subtropical areas (Chen et al., 2015; Li et al., 2015). The conventional breeding of sugarcane is a long and hardworking research. It usually takes 10 years to develop a new variety. Therefore, breeders often introduce new sugarcane varieties (lines) from abroad and screen out healthy germplasm under local climate conditions. It is one of important methods of germplasm innovation and application in sugarcane breeding. Sugarcane introduction is an effective way to make rapid and easy use of sugarcane varieties from all over the world, to optimize the structure of sugarcane varieties in China and increase genetic resources. However, all sugarcane materials from abroad must be quarantined for diseases that recorded in the List of Import Phytosanitary Pests in the People's Republic of China, like sugarcane Fiji disease virus (FDV), sugarcane leaf scald, phytoplasma and sugarcane downy mildew that are not seriously infected in the main production area of Guangxi, thus to prevent serious losses from the introduction of foreign diseases into China.

Sugarcane FDV and leaf scald diseases are the main objects of worldwide quarantine. Sugarcane FDV disease is infected by Fiji leaf gall (FLG). It was first found in Fiji, 1886 and also in Australia, 1890. It is now found in the Philippines, Papua New Guinea, Thailand, Western Samoa and other countries, since it is regarded as the most important disease in Australia, Asia and Pacific region (Smith and Candy, 2004). After sugarcane infected with FDV, the cane stalk was significantly dwarfed and the upper leaf was short as a sword, finally the whole leaves showed fan-shaped. Sugarcane infected with FDV grew a cluster of plants, usually short leaves were found without cane stalks, so that it caused serious reduction of yield (Egan and Ryan, 1986). Leaf scald disease is 
caused by Xanthomonas albilineans (Ashby Dowson). It has been reported in many countries and regions, such as USA, Cambodia, Vietnam, Thailand and so on, where outbreaks have caused huge economic losses (Hoy and Grisham, 1994; Rott et al., 1995; Saumtally et al., 2004). It also has been reported in Guangxi, Hainan and Fujian of China, especially in recent years, sugarcane varieties easily infected with leaf scald have been popularized and planted, resulting in more severe leaf scald disease (Li et al., 2018; Wei et al., 2018).

In order to understand the disease resistance of 41 sugarcane varieties (materials) introduced by Suguarcane Research Institute of Guangxi Academy of Agricultural Sciences from USA and Vietnam as well as their characteristics under local climate conditions in Guangxi, sugercane FDV and leaf scald diseases were detected and important agronomic traits were observed in this study, which would help explore the utilization potential of these introduced sugarcane germplasms in sugarcane breeding in Guangxi and provide important information and reference for sugarcane hybrid parents.

\section{Results and Analysis}

\subsection{Status of diseases in quarantine cultivation}

During the period of quarantine monitoring, the status of diseases was recorded once a month. After two growth cycle of monitoring, 41 introduced sugarcane varieties grew well and no quarantine diseases occurred.

\subsection{Detection of sugarcane leaf scald disease by PCR}

The detection of leaf scald disease by PCR was carried out in 41 sugarcane varieties. The results showed that no bands were amplified in the negative control, while the target band of $600 \mathrm{bp}$ was amplified in the positive control. At the same time, the target band of $600 \mathrm{bp}$ was also not amplified in 41 sugarcane materials, and the identification result was negative (Figure 1; Table 1). The results indicated that 41 sugarcane germplasms introduced from USA and Vietnam were not infected with leaf scald disease.

\subsection{Detection of sugarcane Fiji disease by RT-PCR}

The detection of sugarcane FDV by RT-PCR was carried out in 41 introduced sugarcane varieties. The target band of $450 \mathrm{bp}$ was not amplified and the results were negative (Figure 2; Table 1).

\subsection{Observation of other diseases}

Besides leaf scald and FDV diseases, other common diseases such as red rot, yellow spot, ring spot, pokkah boeng, mosaic, smut, rust and brown stripe disease were also observed in the field. The results showed that 18 of 41 imported materials were not infected with these diseases, other 29 materials were infected with one or more diseases (Table 1).

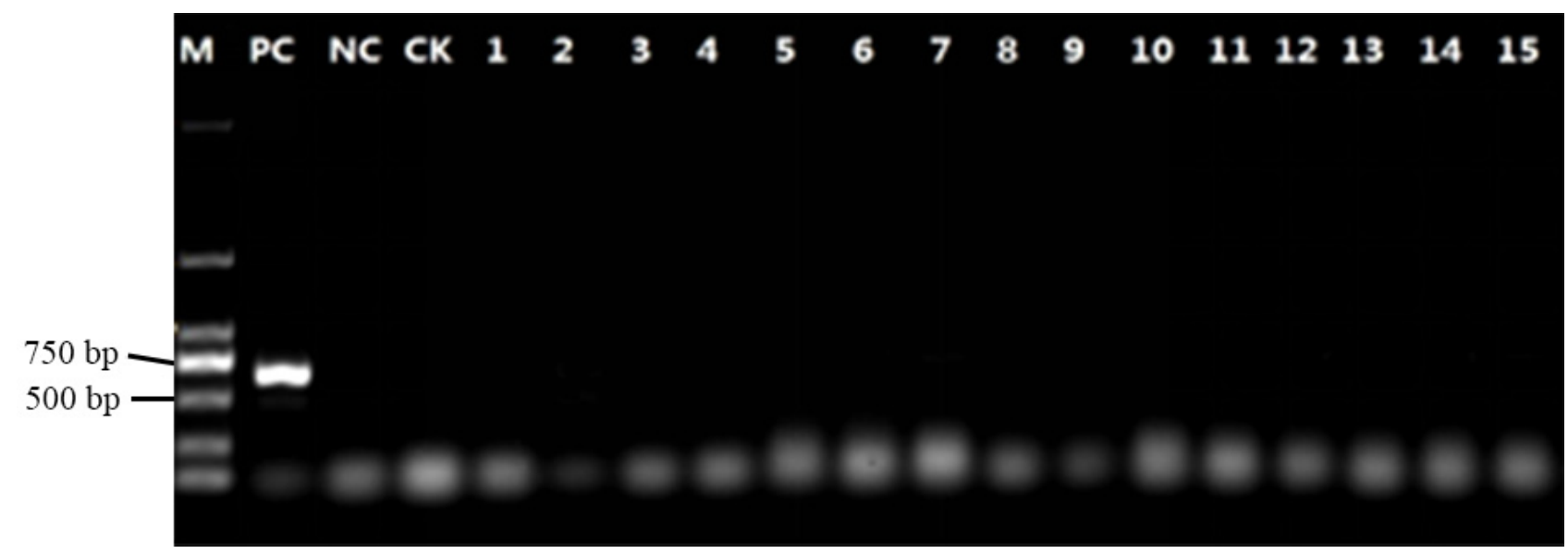

Figure 1 PCR amplification of sugarcane leaf scald

Note: M: DNA ladder marker (D2000); PC: Positive control; NC: Negative control; CK: Blank control; 1 15: No.1 15 materials as listed in Table 1 
Molecular Plant Breeding 2019, Vol.10, No.13, 100-107

http://genbreedpublisher.com/index.php/mpb

Table 1 Disease detection of 41 introduced sugarcane materials

\begin{tabular}{|c|c|c|c|c|c|}
\hline \multirow[t]{2}{*}{ Code } & \multirow[t]{2}{*}{ Materials } & \multicolumn{2}{|c|}{ PCR detection results } & \multirow{2}{*}{$\begin{array}{l}\text { Field survey results } \\
\text { Other diseases }\end{array}$} & \multirow[t]{2}{*}{ Importing country } \\
\hline & & Fiji disease & Leaf scald & & \\
\hline 1 & CPCL97-2730 & - & - & Not found & USA \\
\hline 2 & CPCL02-6848 & - & - & Red rot + , yellow spot + , ring spot + , pokkah boeng + & USA \\
\hline 3 & CPCL00-4111 & - & - & Not found & USA \\
\hline 4 & CPCL02-1295 & - & - & Red rot++ & USA \\
\hline 5 & СР05-1526 & - & & Not found & USA \\
\hline 6 & CPCL05-1791 & - & - & Not found & USA \\
\hline 7 & CPCL99-1401 & - & - & Not found & USA \\
\hline 8 & CPCL95-2287 & - & - & Mosaic + & USA \\
\hline 9 & CPCL02-0926 & - & - & Not found & USA \\
\hline 10 & CPCL05-1201 & - & - & Ring spot ++ & USA \\
\hline 11 & СР00-1446 & - & - & Ring spot + & USA \\
\hline 12 & СР06-2400 & - & - & Not found & USA \\
\hline 13 & СР06-2402 & - & - & Yellow leaf virus+++ & USA \\
\hline 14 & СР09-4229 & - & - & Smut++ & USA \\
\hline 15 & СР04-1566 & - & - & Not found & USA \\
\hline 16 & СР04-1844 & - & - & Yellow spot ++ , ring spot ++ & USA \\
\hline 17 & СР04-1935 & - & - & Yellow leaf virus ++ , yellow spot ++ , smut ++ & USA \\
\hline 18 & L03-371 & - & - & Mosaic + & USA \\
\hline 19 & L01-299 & - & - & Not found & USA \\
\hline 20 & Но05-961 & - & - & Mosaic +++ & USA \\
\hline 21 & LCP85-384 & - & - & Ring spot + & USA \\
\hline 22 & Ho07-613 & - & - & Not found & USA \\
\hline 23 & НоСР00-950 & - & - & Mosaic + , red rot ++ & USA \\
\hline 24 & НоСР85-845 & - & - & Ring spot ++ & USA \\
\hline 25 & НоСР96-540 & - & - & Not found & USA \\
\hline 26 & LCP04-838 & - & - & Smut+ & USA \\
\hline 27 & L01-283 & - & - & Not found & USA \\
\hline 28 & VN08-207 & - & - & Pokkah boeng++ & Vietnam \\
\hline 29 & VN66-03 & - & - & Not found & Vietnam \\
\hline 30 & VN84-4137 & - & - & Rust+++ & Vietnam \\
\hline 31 & VN09-213 & - & - & Not found & Vietnam \\
\hline 32 & VN66-06 & - & - & Not found & Vietnam \\
\hline 33 & VN09-391 & - & - & Not found & Vietnam \\
\hline 34 & VN99-838 & - & - & Smut+ & Vietnam \\
\hline 35 & VN09-450 & - & - & Rust ++ , ring spot ++ & Vietnam \\
\hline 36 & VN08-260 & - & - & Smut +++ & Vietnam \\
\hline 37 & VN84-1745 & - & - & Ring spot++ & Vietnam \\
\hline 38 & VN08-05 & - & - & Yellow leaf virus++ & Vietnam \\
\hline 39 & VN09-284 & - & - & Not found & Vietnam \\
\hline 40 & VN08-235 & - & - & Ring spot++ & Vietnam \\
\hline 41 & VN99-317 & - & - & Smut + , brown stripe + & Vietnam \\
\hline
\end{tabular}

Note: -: PCR result was negative; +: Mild disease; ++: Moderate disease; +++: Severe disease

The fields agronomic characters of 41 introduced sugarcane germplasm were observed and tested (Table 2). The results showed that 12 germplasm (CPCL97-2730, CPCL02-6848, CPCL02-1295, CP05-1526, CPCL02-0926, CP04-1935, LCP85-384, LCP04-838, VN66-03, VN84-4137, VN09-213 and VN66-06) had better comprehensive traits and higher yield potential, which will be entered the next round of variety comparison trials continue to screen. The other 29 germplasm showed poor performance, and we suggested entering the sugarcane resource nursery for further study and utilization. 


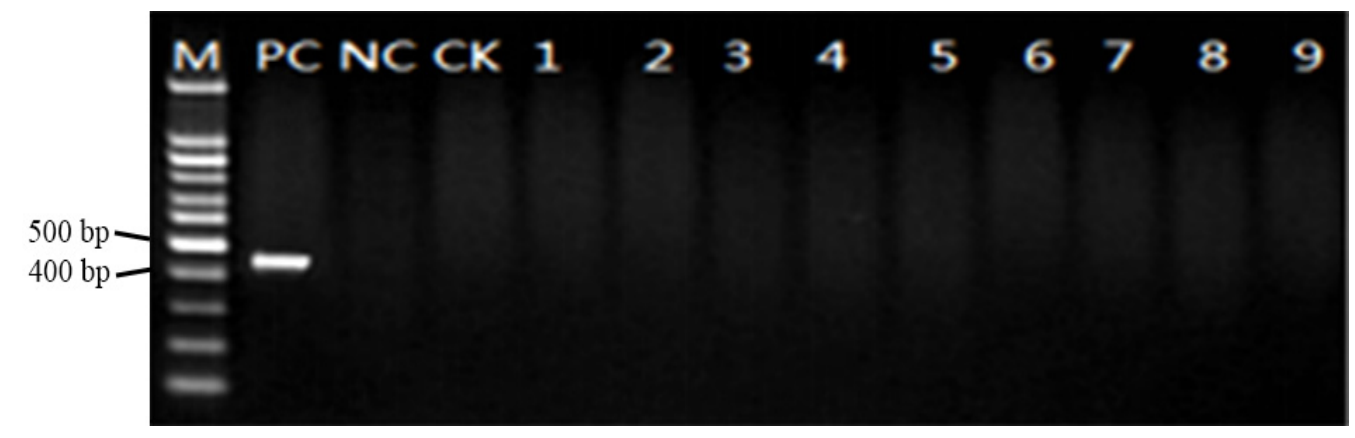

Figure 2 RT-PCR amplification of sugarcane Fiji disease

Note: M: DNA ladder marker (D1500); PC: Positive control; NC: Negative control; CK: Blank control; 1 9: No.1 9 materials as listed in Table 1

Germplasm resources of sugarcane are important basic materials for sugarcane genetics and breeding. The introduction of different sugarcane germplasm with higher heterogeneity from abroad could greatly enrich the gene pool of sugarcane germplasm in China, which might be of great significance for sugarcane breeding. The introduced varieties often perform well at abroad, but in China, with the different domestic climatic conditions, they are difficult to accept. Therefore, it is necessary to carry on field experiment observation to introduce germplasm, and to screen excellent germplasm with good agronomic characters, high yield, high sugar content, and strong ratooning ability for production or for sugarcane genetic breeding.

The introduction of germplasm resources from abroad must be quarantined. The import and export of sugarcane must go through strict quarantine to exchange germplasm resources. Otherwise, it would be easy to cause new diseases to break out in sugarcane area. Leaf scald is a worldwide disease, the potential threat is greater, and there is a tendency to aggravate the disease in recent years. Some new sugarcane varieties (lines) have been found to be infected with this disease in Guangxi sugarcane area ( $\mathrm{Li}$ et al., 2018; Wei et al., 2018). PCR detection and sequencing were effective methods for identification of leaf scald. Wei et al. (2018) and Li et al. (2018) successfully confirmed that sugarcane leaf scald in sugarcane region of Guangxi was caused by Xanthomonas albicans in Xanthomonas using PCR technique. Sugarcane Fiji disease virus is a kind of virus disease which is one of the important diseases of sugarcane like sugarcane leaf scald and has great influence on sugarcane yield. Sugarcane Fiji disease virus has been reported in Fujian experimental nursery and germplasm resource nursery in China (Zhou et al., 1987). It has also been reported in sugarcane varieties imported from abroad in Guangxi (Deng, 1997). At present, the disease has not been found in domestic production. In Yunnan province, RT-PCR technique was used to detect 11 sugarcane varieties from Australia, and no Fiji disease virus was found (Lu et al., 2009). The most fundamental way to control sugarcane Fiji disease virus and leaf scald would be to strengthen quarantine and prohibit the transfer of sugarcane species from endemic areas and plant resistant varieties. In this study, 41 sugarcane materials were introduced from the United States and Vietnam. After two growth cycles of isolated planting, there were no specific bands for sugarcane leaf scald (600 bp) and Fiji disease virus (450 bp) be detected by laboratory test using mature PCR technique. Therefore, agronomic characters were observed. Field experiments results showed that 17 introduced germplasm had strong resistance to disease, except for sugarcane leaf scald and Fiji disease virus, and there was no common disease was found, like red rot, yellow spot, ring spot, pokkah boeng, mosaic, smut, rust, brown stripe diseases and so on. The disease resistance and agronomic characters of eight American sugarcane germplasms (CPCL97-2730, CPCL02-6848, CPCL02-1295, CPCL05-1526, CPCL02-0926, CP04-1935, LCP85-384, LCP04-838), and four Vietnamese sugarcane germplasms (VN66-03, VN09-213, VN66-06, VN09-284) were all good. These materials could be used as hybrid parents in the next round of comparative trials. Other unselected materials would be evaluated for agronomic characters, such as without superior traits (high yield or high sugar content) would be suggested to enter the resource nursery for planting and preservation, and for those with excellent agronomic traits would be considered put in the sugarcane parent nursery for future sugarcane cross breeding. 
Molecular Plant Breeding 2019, Vol.10, No.13, 100-107

http://genbreedpublisher.com/index.php/mpb

Table 2 The agronomic traits in 41 introduced sugarcane germplasm materials

\begin{tabular}{|c|c|c|c|}
\hline Code & Material & Agronomic trait & Note \\
\hline 1 & CPCL97-2730 & $\begin{array}{l}\text { Medium stalk, tight leaf sheath, lodging, dwarf, rich millable stalks, } \\
\text { vigorous growth }\end{array}$ & Enter next field trial \\
\hline 2 & CPCL02-6848 & $\begin{array}{l}\text { Medium stalk, easily defoliated leaf sheaths, erect, tall, good tillering, } \\
\text { vigorous growth }\end{array}$ & Enter next field trial \\
\hline 3 & CPCL00-4111 & Medium small stalk, rich millable stalks, leaf sheath, average growth & Enter germplasm nursery \\
\hline 4 & CPCL02-1295 & $\begin{array}{l}\text { Medium -medium big stalk, more millable stalks, defoliate, tall, vigorous } \\
\text { growth }\end{array}$ & Enter next field trial \\
\hline 5 & СР05-1526 & $\begin{array}{l}\text { Medium stalk, rich millable stalks, easily defoliate leaf sheaths, vigorous } \\
\text { growth }\end{array}$ & Enter next field trial \\
\hline 6 & CPCL05-1791 & Medium stalk, average millable stalks, leaf sheath, dwarf, average growth & Enter germplasm nursery \\
\hline 7 & CPCL99-1401 & Small stalk, leaf sheath, dwarf, average growth & Enter germplasm nursery \\
\hline 8 & CPCL95-2287 & Small stalk, rich millable stalks, leaf sheath, booting stage & Enter germplasm nursery \\
\hline 9 & CPCL02-0926 & Medium small stalk, rich millable stalks, tall, leaf sheath, vigorous growth & Enter next field trial \\
\hline 10 & CPCL05-1201 & Small stalk, average millable stalks, dwarf, leaf sheath & Enter germplasm nursery \\
\hline 11 & CP00-1446 & medium to small stalk, average millable stalks, leaf sheath & Enter germplasm nursery \\
\hline 12 & СР06-2400 & Medium stalk, average millable stalks, dwarf, leaf sheath & Enter germplasm nursery \\
\hline 13 & СР06-2402 & Medium small stalk, rich millable stalks, dwarf & Enter germplasm nursery \\
\hline 14 & СР09-4229 & Medium stalk, rich millable stalks, bad growth & Enter germplasm nursery \\
\hline 15 & СР04-1566 & Medium stalk, rich millable stalks, bad growth & Enter germplasm nursery \\
\hline 16 & СР04-1844 & Medium stalk, poor millable stalks, bad growth & Enter germplasm nursery \\
\hline 17 & СР04-1935 & $\begin{array}{l}\text { Medium small stalk, rich millable stalks, plant erect, easily defoliate, tiller } \\
\text { good, vigorous growth }\end{array}$ & Enter next field trial \\
\hline 18 & L03-371 & Medium stalk, rich millable stalks, leaf sheath, average growth & Enter germplasm nursery \\
\hline 19 & L01-299 & small stalk, rich millable stalks, leaf sheath, average growth & Enter germplasm nursery \\
\hline 20 & Ho05-961 & small stalk, rich millable stalks, average growth & Enter germplasm nursery \\
\hline 21 & LCP85-384 & Medium stalk, rich millable stalks, vigorous growth & Neter next field trial \\
\hline 22 & Ho07-613 & small stalk, rich millable stalks, vigorous growth & Enter germplasm nursery \\
\hline 23 & НоСР00-950 & small stalk, poor millable stalks, average growth & Enter germplasm nurser \\
\hline 24 & HoCP85-845 & Medium small stalk, poor millable stalks, bad growth & Enter germplasm nursery \\
\hline 25 & НоСР96-540 & Medium small stalk, poor millable stalks, average growth & Enter germplasm nursery \\
\hline 26 & LCP04-838 & Medium stalk, rich millable stalks, average growth & Enter next field trial \\
\hline 27 & L o01-283 & small stalk, bad growth & Enter germplasm nursery \\
\hline 28 & VN08-207 & Medium stalk, poor millable stalks, bad growth & Enter germplasm nursery \\
\hline 29 & VN66-03 & Medium stalk, rich millable stalks, average growth & Enter next field trial \\
\hline 30 & VN84-4137 & Medium stalk, rich millable stalks, vigorous growth & Enter next field trial \\
\hline 31 & VN09-213 & Medium stalk, rich millable stalks, average growth & Enter next field trial \\
\hline 32 & VN66-06 & Medium samll stalk, rich millable stalks, average growth & Enter next field trial \\
\hline 33 & VN09-391 & Medium stalk, poor millable stalks, bad growth & Enter germplasm nursery \\
\hline 34 & VN99-838 & Medium stalk, rich millable stalks, average growth & Enter germplasm nursery \\
\hline 35 & VN09-450 & Medium stalk, rich millable stalks, average growth & Enter germplasm nursery \\
\hline 36 & VN08-260 & small stalk, rich millable stalks, dwarf, bad growth & Enter germplasm nursery \\
\hline 37 & VN84-1745 & Medium stalk, average millable stalks, leaf sheath, bad growth & Enter germplasm nursery \\
\hline 38 & VN08-05 & Medium to small stalk, average millable stalks, bad growth & Enter germplasm nursery \\
\hline 39 & VN09-284 & Medium to small stalk, rich millable stalks, average growth & Enter germplasm nursery \\
\hline 40 & VN08-235 & Medium stalk, rich millable stalks, leaf sheath, average growth & Enter germplasm nursery \\
\hline 41 & VN99-317 & Small stalk, poor millable stalks, medium growth & Enter germplasm nursery \\
\hline
\end{tabular}

The PCR technology has been widely used in the disease detection of various crops, and gradually became a necessary means for the inspection of import and export plant quarantine ( $\mathrm{Lu}$ et al., 2009; Li et al., 2016; Peng et 
al., 2018). It is a guarantee for the healthy development of sugarcane industry and the cooperation and exchange at home and abroad to apply quarantine detection techniques and standardized quarantine procedures, and carry on the quarantine of Disease and insect pests for import and export sugarcane germplasm resources. In this study, the disease surveillance was carry out in strict accordance with the quarantine procedure of the import and quarantine of the sugar cane, disease symptom observation combined with molecular monitoring and the detection of sugarcane pests \& diseases to eliminate new pests and diseases caused by introduction, which was of great significance for the healthy production of sugarcane industry and breeding of sugarcane disease resistance in China.

\section{Materials and Methods}

\subsection{The tested material}

41 sugarcane germplasm materials were introduced from the United States and Vietnam, including 27 sugarcane germplasms from the United States and 14 sugarcane germplasms from Vietnam (Table 3). The samples were collected in the quarantine greenhouse of Sugarcane Research Institute, Guangxi Academy of Agricultural Sciences.

\subsection{Epidemic surveillance}

Strict quarantine monitoring of introduced sugarcane germplasm was carried out. In the pretreatment room of quarantine room, the imported sugarcane germplasm was first unsealed and appearance inspected, then treated with hot water, soaked in hot water at $50{ }^{\circ} \mathrm{C}$ for 2 hours, then soaked with carbendazim $50 \%$ visibility powder 800 times solution for $10 \mathrm{~min}$. Then, the sterilizing soil at $120^{\circ} \mathrm{C}$ was used to plant and cultivated. We put them in different separate greenhouses according to the batches and sources. Observe and monitor diseases and pests on a monthly basis. After $6 \sim 10$ months of planting, 50\% of the sugarcane plants were cut and replanted in barrels. Plant cane and ratoon planted for 6-10 months. Samples were taken for molecular bioassay of Fiji disease virus and leaf scald during cultivation.

\subsection{Sampling and sample preparation}

The sugarcane growing in quarantine greenhouse which was at fourth month fresh +1 leaf of plant cane and ratoon was taken for the detection of Fiji disease virus. The sugarcane cane near the growing point at tenth month was taken for the detection of leaf scald. Sample about $1 \mathrm{~g}$. The sampling tool was washed with water and then disinfected with $75 \%$ alcohol at every time of sampling. The sample was cut into small pieces with knife or scissors, put in a mortar, added liquid nitrogen to grind quickly 4 5 times to powder, and rapidly transferred to 1.5 $\mathrm{mL}$ centrifuge tube, saved at $-80^{\circ} \mathrm{C}$.

\subsection{DNA extraction and RNA extraction of samples}

Wolact $^{\circledR}$ Plant Genomic DNA Purification Kit was used to extract total DNA from leaves for PCR molecular detection of sugarcane leaf scald. Wolact ${ }^{\circledR}$ Plant RNA Isolation Kit was used to extract the sample RNA for RT-PCR detection of sugarcane FDV. The specific steps were carried out according to the operation of the specification.

Table 3 The sugarcane germplasm materials from USA and Vietnam

\begin{tabular}{|c|c|c|c|}
\hline Source & Time & Number & Name of material \\
\hline USA & 2014-11 & 17 & $\begin{array}{l}\text { CPCL97-2730, CPCL02-6848, CPCL00-4111, CPCL02-1295, CP05-1526, CPCL05-1791, } \\
\text { CPCL99-1401, CPCL95-2287, CPCL02-0926, CPCL15-1201, CP00-1446, CP06-2400, } \\
\text { CP06-2402, CP09-4229, CP04-1566, CP04-1844, CP04-1935 }\end{array}$ \\
\hline USA & $2015-4$ & 10 & $\begin{array}{l}\text { HoCP96-540, НоСР85-845, НоСР00-950, Ho07-613, LCP85-384, Ho05-961, L01-283, } \\
\text { L01-299, L03-371 }\end{array}$ \\
\hline Vietnam & $2015-5$ & 14 & $\begin{array}{l}\text { VN 08-05, VN 08-207, VN 08-235, VN 08-260, VN 84-4137, VN 66-06, VN 09-213, VN } \\
09-284, \text { VN 09-391, VN 09-450, VN 66-03, VN 84-1745, VN 99-317, VN 99-838 }\end{array}$ \\
\hline
\end{tabular}




\subsection{Primer design and synthesis}

$X$. allbilineans specific primers for PCR detection of sugarcane leaf scald were designed with reference to Birch (2001). Forward Primer XAF1 : 5'-CCTGGTGATGACGCTGGGTT-3'; downstream primer XAR1: 5'-CGATCAGCGATGCACGCAGT-3'. The size of pre-amplified product was about $600 \mathrm{bp}$.

The primers used for RT-PCR detection of sugarcane Fiji disease virus were Fontana et al. (2013) conserved sequence specific primers of sugarcane Fiji virus. Forward primer FDV7F: 5'-CCGAGTTACGGTCAGACTGTTCTT-3'; downstream primer 5'-CAGTGGTGACGAAATGATGGCGA-3'. The size of the pre-amplified product was about $450 \mathrm{bp}$.

\subsection{PCR amplification and electrophoretic detection of sugarcane leaf scald}

The growth point of sugarcane DNA was used as a template, and the PCR system referred to the method of Wei et al. (2018). System $(20.0 \mu \mathrm{L})$ : DNA sample was $3.0 \mu \mathrm{L}, 2 \times \mathrm{PCR} T a q$ mix $8.0 \mu \mathrm{L}$, each of the forward primer and downstream primer was $0.2 \mu \mathrm{L}(20 \mu \mathrm{g} / \mu \mathrm{L}), \mathrm{ddH}_{2} \mathrm{O} 8.6 \mu \mathrm{L}$. Amplification program: Pre-denaturation at $95^{\circ} \mathrm{C}$ for 5 $\min ; 94^{\circ} \mathrm{C}$ for $45 \mathrm{~s}, 65^{\circ} \mathrm{C}$ for $1 \mathrm{~min}, 72^{\circ} \mathrm{C}$ for $1 \mathrm{~min}, 10$ circles. $94^{\circ} \mathrm{C}$ for $45 \mathrm{~s}, 65^{\circ} \mathrm{C}$ for $1 \mathrm{~min}, 72^{\circ} \mathrm{C}$ for $2 \mathrm{~min}, 10$ circles; $94^{\circ} \mathrm{C}$ for $45 \mathrm{~s}, 65^{\circ} \mathrm{C}$ for $1 \mathrm{~min}, 72^{\circ} \mathrm{C}$ for $3 \mathrm{~min}, 10$ circles; extended at $72^{\circ} \mathrm{C}$ for $10 \mathrm{~min}$. The experiment was repeated 3 times.

The amplified products of $8.0 \mu \mathrm{L}$ were detected by $1.5 \%$ agarose gel electrophoresis. The amplified bands of about $600 \mathrm{bp}$ were positive and the results of no amplified bands were negative. If there were specific bands, they would be taken for recovery and purification, sequencing, BLAST search and analysis.

\subsection{RT-PCR amplification and electrophoretic detection of sugarcane Fiji virus}

+1 leaf RNA samples extracted were detected by one-step RT-PCR with C. therm RT-PCR kit (Li et al., 2016). The actions were as follows: $1.0 \mu \mathrm{L}$ RNA template was added to the $0.5 \mathrm{~mL}$ PCR tube, the upstream and downstream primer $(20 \mu \mathrm{g} / \mu \mathrm{L})$ were $0.25 \mu \mathrm{L}$ and ddH2O $11.0 \mu \mathrm{L}$, respectively. Mix well and place on ice immediately after denaturation at $99^{\circ} \mathrm{C}$ for $2 \mathrm{~min}$, on PCR. In the above mixture, $5 \times$ buffer $5 \mu \mathrm{L}, 10 \% \mathrm{PVP} 2.5 \mu \mathrm{L}$, $100 \mathrm{mmol} / \mathrm{L}$ DDT $1.25 \mu \mathrm{L}, 100 \%$ DMSO $1.25 \mu \mathrm{L}, 5 \%$ BSA $1.0 \mu \mathrm{L}, 20 \mathrm{mmol} / \mathrm{L}$ dNTPs $0.5 \mu \mathrm{L}$ and C. therm enzyme $1.0 \mu \mathrm{L}$ were added in proper order, the total volume of the reaction was $25 \mu \mathrm{L}$. The PCR amplification program: $57^{\circ} \mathrm{C}$ for $30 \mathrm{~min}, 95^{\circ} \mathrm{C}$ for $2 \mathrm{~min}, 95^{\circ} \mathrm{C}$ for $1 \mathrm{~min}, 57^{\circ} \mathrm{C}$ for $1 \mathrm{~min}, 72^{\circ} \mathrm{C}$ for $1 \mathrm{~min}, 35 \mathrm{circles}$, extended at $72^{\circ} \mathrm{C}$ for $10 \mathrm{~min}$, with three times of repeated amplification.

The amplified products of $8.0 \mu \mathrm{L}$ were detected by $1.5 \%$ agarose gel electrophoresis. Taking photos at Image maker VDS Image, the amplified bands of about $450 \mathrm{bp}$ were positive and the results of no amplified bands were negative. If there were specific fragments, recovery and purification, sequencing, BLAST search analysis would be carried on.

\subsection{Evaluation of agronomic traits of sugarcane}

After the introduced sugarcane germplasm was isolated and quarantined, the agronomic character evaluation test was carried out in the field. The introduced sugarcane varieties were harvested after two growing cycles, soaked in flowing cold water for 24 hours, then soaked in hot water of $52^{\circ} \mathrm{C}$ for $30 \mathrm{~min}$, to observe agronomic and other characters in the field. Each variety was planted in 3 rows, each of which had $7 \mathrm{~m}, 80$ buds per row. The varieties were arranged randomly, and the control was the main cultivar ROC22. The agronomic characters were evaluated at the mature stage of the new plant, and the better materials were selected for the subsequent variety comparison test.

\section{Authors' Contributions}

WJJ was the main executors of this research and the writer of this article. SXP, ZXQ, TZQ, ZRH, WCY, GYY, ZH, THW, HDL and LHB completed data collection and analysis. LXH and LYR were the architect and in charge of the project, who guided paper writing and revision. All the authors read and agree to the final text. 


\section{Acknowledgments}

This research was jointly supported by The National Natural Science Foundation of China (31860350), National industrial system (CARS-170105), Guangxi Innovation Team Project of National Industrial System (gjnytxgxcxtd -03-01) Guangxi innovation-driven project (Guike AA17202042-6) and Fund of Guangxi Academy of Agricultural Sciences (Guinongke 2018YT02; 2018YM01; 2017NZ01).

\section{References}

Chen Y., Wang Z.Q., Fu Z.W., Yang Y.T., Guo J.L., Su Y.C., and Xu L.P., 2015, Cloning and expression analysis of metallothionein gene ScMT2-1-4 in sugarcane, Jiyinzuxue Yu Yingyong Shengwuxue (Genomics and Applied Biology), 34(2): 357-364 Birch R.G., 2001, Xanthomonas albilineans and the antipathogenesis approach to disease control, Mol. Plant Pathol., 2(2): 1-11 https://doi.org/10.1046/j.1364-3703.2001.00046.x

Deng Z.Y., 1997, Present situation and prospects of sugarcane introduction and quarantine in Guangxi, Guangxi Tangye (Guangxi Sugar Industry), (4): 20-22

Egan B.T., and Ryan C.C., 1986, Predicting disease incidence and yield losses in sugarcane in a Fiji disease epidemic, In: Mclean G.D., Garrett R.G., and Ruessink W.G. (eds.), Plant virus epidemics: monitoring, modelling and predicting outbreaks, Academic Press, New York, USA, pp.443-457

Fontana P.D., Rago A.M., Fontana C.A., Vignolo G.M., Cocconcelli P.S., and Mariotti J.A., 2013, Isolation and genetic characterization of Acidovorax avenae from red stripe infected sugarcane in northwestern Argentina, Eur. J. Plant Pathol., 137(3): 525-534 https://doi.org/10.1007/s10658-013-0263-y

Hoy J.W., and Grisham M.P., 1994, Sugarcane leaf scald distribution, symptomatology, and effect on yield in Louisiana, Plant Disease, 78(11): 1083-1087 https://doi.org/10.1094/PD-78-1083

Li X.J., Liu H.B., Lin X.Q., Wu Z.D., Xu C.H., and Liu X.L., 2015, In Silico cloning and bioinformatics analysis of KNOX gene in sugarcane (Sckn1), Jiyinzuxue Yu Yingyong Shengwuxue (Genomics and Applied Biology), 34(1): 136-142

Li W.F., Shan H.L., Zhang R.Y., Chang X.Y., Wang X.Y., Yin J., Luo Z.M., and Huang Y.K., 2018, Sugarcane leaf scalddisease found in Guangxi sugarcane region, Zhongguo Nongxue Tongbao (Chinese Agricultural Science Bulletin), 34(13): 144-149

Li W.F., Wang X.Y., Huang Y.K., Shan H.L., Zhang R.Y., Yin J., and Luo Z.M., 2016, Molecular detection techniques of sugarcane important diseases, Zhiwu Baohu (Plant Protection), 42(5): 125-130

Lu W.J., Li W.F., Huang Y.K., Wu C.W., Luo Z.M., and Zhao P.F., 2009, Quarantine and molecular detection for quarantine pest on exotic sugarcane varieties, Yunnan Nongye Daxue Xuebao (Journal of Yunnan Agricultural University), 24(6): 804-808

Mei Z.P., Wang X.H., and Yang Q.H., 2018, Molecular detection of brown rust resistance gene Brul in wild germplasm resources of sugarcane, Fenzi Zhiwu Yuzhong (Molecular Plant Breeding), 16(11): 3495-3503

Rott P., Soupa D., Brunet Y., and Letourmy P., 1995, Leaf scald (Xanthomonas albilineans) incidence and its effect on yield in seven sugarcane cultivars in Guadeloupe, Plant Pathol., 44(6): 1075-1084 https://doi.org/10.1111/j.1365-3059.1995.tb02667.x

Saumtally A.S., Dookun-Saumtally A., Rao G.P., Salem S.A., and Rott P., 2006, Leaf scald of sugarcane: a disease of worldwide importance, pp: 1081-1091 https://doi.org/10.1071/AR03241

Smith G.R., and Candy J.M., 2004, Viewpoint-improving Fiji disease resistance screening trials in sugarcane by considering virus transmission class and possible origin of Fiji disease virus, Aust. J. Agric. Res., 55(6): 665-672

Wei J.J., Wei C.Y., Song X.P., Qin Z.Q., Tan H.W., Zhang R.H., Pang T., Wang L.W., Liu L., and Li Y.R., 2018, Sugarcane leaf scald disease in sugarcane planting areas of Beihai, Guangxi, Nanfang Nongye Xuebao (Journal of Southern Agriculture), 49(2): 264-270

Zhou Z.J., Xie L.H., Lin Q.Y., Cai X.T., and Wang H., 1987, Identification of sugarcane Fiji disease virus in Fujian Province, Bingdu Xuebao (Chinese Journal of Virology), 3(3): 302-304 